\title{
¿ R Research S Suare on \\ Fly Ash Based Geopolymers With Refractoriness Properties in the Context of Circular Economy
}

\section{Katarzyna Zarębska ( $\nabla$ zarebska@agh.edu.pl) \\ AGH University of Science and Technology https://orcid.org/0000-0002-7305-9762}

Piotr Zabierowski

AGH University of Science and Technology

Magdalena Gazda-Grzywacz

AGH University of Science and Technology

Natalia Czuma

AGH University of Science and Technology

Paweł Baran

AGH University of Science and Technology

\section{Research Article}

Keywords: fly ash from lignite combustion, geopolymers, coal combustion wastes, circular economy, clean coal technology

Posted Date: August 23rd, 2021

DOI: https://doi.org/10.21203/rs.3.rs-802844/v1

License: (a) (i) This work is licensed under a Creative Commons Attribution 4.0 International License. Read Full License 


\section{Abstract}

Nowadays appropriate waste management, along with efficient use of natural resources and implementing the concept of circular economy are an issue of high concern. The aim of the research was to synthesize geopolymers showing insulating properties, with specific strength and refractoriness parameters. For this purpose, waste from the energy sector was used which is produced in large quantities. The analyses were an attempt to manage fly ashes according to the concept of circular economy. For the synthesis of geopolymers perlite additive was used, the literature on the subject indicated that its addition had a positive effect on the refractoriness of the obtained materials. The SII4 geopolymer fully meets the requirements for thermal insulation in Poland $(0.086 \mathrm{~W} / \mathrm{m} \bullet \mathrm{K})$, as a material for single-layer walls. Of the two variables analyzed in the study, i.e., the influence of the mixture composition on the synthesis and the curing temperature of the geopolymer, only the first had a significant influence on the value of the thermal conductivity coefficient.

\section{Highlights}

- Waste management, along with efficient use of natural resources and implementing the concept of circular economy;

- Synthesize geopolymers showing insulating properties, with specific strength and refractoriness parameters;

- Waste from the energy sector.

\section{Introduction}

According to the International Energy Agency (IEA) ("IEA. Market Report Series: Coal 2018," 2018), about 40\% of the world's energy is produced from coal. In some countries, e.g., South Africa, China, Australia and Poland, this raw material is the dominant fuel in the energy mix. In Poland, at the end of 2017, the share of hard coal in electricity generation was $46.4 \%$ and that of lignite was $30.6 \%$ (Central Statistical Office, GUS, Energy, 2019). The biggest problem in the power industry is the emission of exhaust fumes and the generation of socalled coal combustion products (CCPs). CCPs include boiler slag, bottom ash, gypsum and fly ash. Every year, in Europe, over 100 million tonnes CCPs are produced. Poland is one of the leading producers of this type of waste in Europe. The generation and supply of electricity generate $15.4 \%$ of the total amount of waste in Poland, and of this, $5.3 \%$ is fly ash from coal and mixtures of fly ash and calcium-based solid wastes from flue-gas desulphurization plants. This gives a total of approximately six million tonnes of residues from the combustion of the raw material (Central Statistical Office, Environmental Protection, 2019; Stopińska, 2015).

According to ECOBA, in the EU (UE-15) in $2016 \mathrm{ca} .40 \mathrm{mln}$ tonnes of CCP were produced. The majority of CCP is fly ash, product of electrostatic and mechanic sedimentation of particles such as combustion product particles. Within the EU ca. $43 \%$ of fly ash is being reused in the construction industry, similarly, $46 \%$ of bottom ash and 100\% of boiler slag (access: 02.02.2021 http://www.ecoba.com/ecobaccputil.html).

According to a recent report, in Poland in 2018 , ca. 2.43 mln tonnes of fly ash from coal combustion, as well as $2,58 \mathrm{mln}$ tonnes of mixed fly ash and solid waste from calcium-based methods of waste gases 
desulphurization were produced. Only 33,7 thousand tonnes of fly ash have been recycled (Central Statistical Office, Environmental Protection, 2019, Central Statistical Office, GUS, Energy, 2019).

The management of fly ash from coal combustion is a problem and a huge challenge because the amount produced is so large that it is difficult to recycle. The problem of the ecological disposal of fly ash has not yet found a final solution.

Appropriate waste management, especially in the energy sector, is an important issue, ensuring efficient use of natural resources while minimizing negative impacts on the environment and human health. The European Commission has already proposed a "Zero Waste Europe" program, starting in 2014 (Communication from the Commission to the European Parliament, the Council, the European Economic and Social Committee and the Committee of the Regions Towards a closed-loop economy: the zero-waste programme for Europe, 2014), aimed at full recycling and reducing the consumption of natural reserves. In connection with the constant tightening of environmental regulations, especially in the European Union, concerning emissions and greenhouse gas emissions, as well as the production and storage of CCPs, it is important to develop and introduce a circular economy (Erkman, 1997; Lieder and Rashid, 2016; Pires and Martinho, 2019; Sauvé et al., 2016). This concept involves the reusage of resources and the extension of the life cycle (Rosiek, 2018; Sathish et al., 2019). The circular economy offers a model for managing processes or entire technologies, allowing for the management of previously generated waste. The current economy is of a consumer-driven nature and favors generating large quantities of various types of waste, which is often hazardous and difficult to manage. The circular economy may be the future for the industry, especially the energy industry, allowing for an efficient use of raw materials and improvements in the condition of the environment. It is therefore beneficial to develop fly ash following the circular economy concept and clean coal technology (CCT) processes. CCTs create the possibility of using coal in such a way as to minimize the negative impact of coal processing on the environment while maintaining the sustainable development of the power industry (Çelik et al., 2019; Xu et al., 2017). CCTs refer to the entire coal chain, i.e., from coal mining, coal processing and transport, to the management of wastes from extraction and both processing and use of raw materials and products (Kasztelewicz et al., 2009).

As a result of many years of research, a method of utilization of fly ashes from the power industry has been developed, based on intensive work on the synthesis of geopolymers (Baran et al., 2017; Bubshait et al., 1996; Paprocki and Oyrzanowski, 1975; Perumal et al., 2019; Vaičiukynienè et al., 2018; Van Deventer et al., 2012; Zarębska et al., 2019). Geopolymers are inorganic polymeric aluminosilicate materials, similar to the ceramic material. Their Si-O-Al structure (tetrahedral chains of $\left[\mathrm{SiO}_{4}\right]$ and $\left[\mathrm{AlO}_{4}\right]$ ) forms a three-dimensional network (Koleżyński et al., 2018; Kumar and Kumar, 2011; Ma et al., 2018). These materials consist of long chains (copolymers) of silicon and aluminum oxides, metal cations stabilizing them, most often sodium, potassium or lithium and bound water (Duxson et al., 2007). It has been confirmed that geopolymer cement concrete could be an attractive alternative to standard building materials, due to its high compressive strength, good resistance to acids and low thermal conductivity, depending on the choice of raw material and the processing conditions (Provis and Bernal, 2014). Due to the high availability of raw materials for synthesis and the relative ease of processing, as well as their promising properties, geopolymers can be used in the construction sector, both as construction materials and as insulators. Geopolymers can be substituted for the commonly used Portland cement. The production of building materials, especially highly processed materials, is 
associated with significant environmental damage. During the production of Portland cement, significant quantities of carbon dioxide are generated. $\mathrm{CO}_{2}$ emissions per tonne of clinker are currently around $807 \mathrm{~kg}$. The cement industry worldwide is responsible for ca. $5 \%$ of total $\mathrm{CO}_{2}$ emissions. The vast majority $(63 \%)$ of $\mathrm{CO}_{2}$ emissions from cement plants are process emissions. During clinker production, calcium carbonate is broken down into calcium oxide and carbon dioxide. This emission cannot be eliminated (Giesekam et al., 2016; Parshwanath et al., 2011; PCA, Polish Cement Association. CO2 changes the face of the cement industry, 2019; Teixeira et al., 2019). Therefore, it has become important to search for new, pro-ecological solutions and to develop methods of synthesis for materials that can substitute for commercial cement. Recently, studies have been published, stating the environmental harmfulness of concrete, the production process of which is related to high $\mathrm{CO} 2$ emissions (Crossin, 2012; Naik, 2008)]. So far, numerous solutions have been developed, such as mixed cement or cement with clincker. Methods of substitution of raw materials with recycled or reused materials have been developed as well. In order to objectively assess the environmental legitimacy of application of substitutive materials for cement in concrete, the Life Cycle Assessment (LCA) is recommended. The LCA is also used for assessment of geopolymeric cement-concrete products. In their work, Yang et al. (Yang et al., 2013) have described the procedure of $\mathrm{CO}_{2}$ emission reduction assessment in concrete manufacturing. The system they had analyzed included all the steps, from cradle to prefabrication. Also, the $\mathrm{CO}_{2}$ emission reduction in precast concrete elements had been assessed, based on some practical examples where cement from ground granulated blast furnace slag had been replaced by a bond (Yang et al., 2013). Salas et al. (Salas et al., 2018), in their work about geopolymeric materials have proven that because of high energy consumption, the phase of sodium hydroxide production has the most negative impact on the environment, in reference to the whole life cycle of these materials. It has been shown that the production of geopolymers is environmentally justified, as compared to traditional concrete, if a good part of energy used for sodium hydroxide production comes from renewable sources (Salas et al., 2018). Geopolymers synthesized from fly ash may be materials that can meet the requirements to be competitive with Portland cement, both in terms of properties and in terms of ecology. Many methods of geopolymer synthesis have been developed, and the influence of the formula on the properties of the materials obtained has been determined (Vaou and Panias, 2010). However, these methods are often contradictory, both in terms of the amount of alkaline activator used and of properties such as the increase in geopolymer cement concrete strength as a function of seasoning time. The causes of differences in the results of geopolymer studies are likely to be both the type and the source of the fly ash. In the power industry, the ash can originate from both hard coal and lignite coal combustion, various combustion methods (dust or fluidized bed boilers) and various flue-gas dedusting systems or ash collection sites, e.g., boilers. For this reason, it is important to synthesize geopolymers individually for the region concerned, from fly ash from the power industry characterized by a given specification of raw materials and technology. In the present paper, geopolymers were synthesized using both fly ash from coal combustion and perlite (Rattanasak and Chindaprasirt, 2009), with different volumes and types of alkaline activator (Cheng and Chiu, 2003; “PN-EN 993 - 12:2000 Refractory materials - Test methods for compact, formed and informal refractory products - Determination of equivalent pyrometric cone (ordinary fire resistance)," 2000). The research was aimed at the synthesis of geopolymers showing insulating properties, with determined their strength and refractoriness parameters. The selection of waste from the energy sector which is produced in large volumes was directed at an attempt to 
manage fly ash according to the circular economy concept. The application of perlite was driven by its chemical composition and testing its influence on insulating properties.

\section{Materials And Methods}

In the experimental part, the raw materials used were both dry and wet. Among the dry ones, fly ash and perlite were used, among the wet one's sodium and potassium water glass, $\mathrm{NaOH}$ and $\mathrm{KOH}$ alkaline solutions and $\mathrm{H}_{2} \mathrm{O}_{2}$ solution.

\subsection{Fly ash}

In the study fly ash from brown coal combustion was used. The oxide composition of fly ash used for the ash syntheses was determined using an Epsilon 3 ED-XRF spectrometer from PANalytical. The results of the analysis are presented in Table 1.

Table 1. Oxide content of fly ash.

\begin{tabular}{|c|c|c|c|c|c|c|c|c|c|c|c|c|}
\hline \multicolumn{13}{|c|}{ Mass content of oxides, [\%] } \\
\hline $\mathrm{Na}_{2} \mathrm{O}$ & $\mathrm{MgO}$ & $\mathrm{Al}_{2} \mathrm{O}_{3}$ & $\mathrm{SiO}_{2}$ & $\mathrm{P}_{2} \mathrm{O}_{5}$ & $\mathrm{SO}_{3}$ & $\mathrm{~K}_{2} \mathrm{O}$ & $\mathrm{CaO}$ & $\mathrm{TiO}_{2}$ & $\mathrm{MnO}$ & $\mathrm{Fe}_{2} \mathrm{O}_{3}$ & LOI & $\begin{array}{l}\text { Free } \\
\mathrm{CaO}\end{array}$ \\
\hline 0.01 & 1.34 & 19.67 & 45.25 & 0.12 & 2.00 & 0.15 & 19.50 & 1.54 & 0.03 & 4.60 & 3.70 & 2.80 \\
\hline
\end{tabular}

Its mineral composition, determined by X-ray powder diffraction (XRD) using a Philips X'pert avalanche photodiode diffractometer with a PW 3020 goniometer, a Cu tube and a graphite monochromator is presented in Figure 1.

The fly ash used is composed mainly of quartz and mullite, calcium carbonate and calcium sulphate have been identified as well. The morphology of fly ash has been visualized in Fig 2.

\subsection{Perlite}

The selected expanded perlite is EP 150 (Class 1). Its chemical composition includes the following compounds: $\mathrm{SiO}_{2}(65-73 \%) \mathrm{Al}_{2} \mathrm{O}_{3}(10-18 \%) \mathrm{K}_{2} \mathrm{O}+\mathrm{Na}_{2} \mathrm{O}(6-9 \%) \mathrm{CaO}(2-6 \%) \mathrm{Fe}(1-2 \%)$. It has a grain size of 0.25 to $1.0 \mathrm{~mm}$. It is characterized by a bulk density of $40-90 \mathrm{~kg} / \mathrm{m}^{3}$. The moisture content is of $2 \%$ maximum. It is an odorless granulate with a $\mathrm{pH}$ of $6.5-7.5$. At high temperatures above $900^{\circ} \mathrm{C}$, it melts. Due to the thermal conductivity coefficient of $0.045-0.059 \mathrm{~W} / \mathrm{m} \cdot \mathrm{K}$, it is used to improve the insulation properties. Compressive strength is in the range of $0.14-0.40 \mathrm{MPa}$. The specific heat of the substance is $0.96-0.92 \mathrm{~kJ} / \mathrm{kg} \cdot \mathrm{K}$.

The other type of used perlite, the non-expanded one, is a naturally occurring rock of volcanic origin which is not processed. It is characterized by a much higher density compared to the expanded one. Its bulk density is of $900-1200 \mathrm{~kg} / \mathrm{m}^{3}$. This property is due to the higher water content in its structure: $2-5 \%$. Non-expanded perlite grains are 5 times smaller and its thermal conductivity coefficient is about 2 times higher, while the chemical composition and melting point are the same as in the case of expanded perlite. 


\subsection{Liquids}

For the synthesis, additional components were used: sodium and potassium water glass (Avantor company), two solutions of $\mathrm{NaOH}$ and $\mathrm{KOH} 8 \mathrm{~mol} / \mathrm{dm}^{3}$ and $30 \% \mathrm{H}_{2} \mathrm{O}_{2}$ solution.

\section{Composition Of Mixtures And Conditions For Geopolymer Synthesis}

The synthesis of geopolymers was preceded by the preparation of mixtures for synthesis. They were divided into two sets.

The first set designated $\mathrm{SI}$, consisted of the synthesis of five geopolymers, using the following liquid components: $8 \mathrm{~mol} / \mathrm{dm}^{3}$ solution of $\mathrm{KOH}$ and potassium water glass in a 1:2 mass ratio, as well as solid components: expanded perlite or a mixture of expanded perlite and one of the additives: non-expanded perlite or fly ash in a 1:1 mass ratio. The conditions and formula used for the synthesis are presented in Table 2 below.

Table 2

Substrates and conditions for geopolymer synthesis based on $\mathrm{KOH}$ : SI series.

\begin{tabular}{|c|c|c|c|c|c|}
\hline Sample data & SI 1 & SI 2 & SI 3 & SI 4 & SI 5 \\
\hline $\begin{array}{l}\text { Liquid } \\
\text { components }\end{array}$ & $\begin{array}{l}1: 2 \\
\text { KOH/PWG }\end{array}$ & $\begin{array}{l}1: 2 \\
\mathrm{KOH} / \mathrm{PWG}\end{array}$ & $\begin{array}{l}1: 2 \\
\mathrm{KOH} / \mathrm{PWG}\end{array}$ & $\begin{array}{l}1: 2 \\
\mathrm{KOH} / \mathrm{PWG}\end{array}$ & $\begin{array}{l}1: 2 \\
\mathrm{KOH} / \mathrm{PWG}\end{array}$ \\
\hline Mass of liquids, g & 219.4 & 219.7 & 219.4 & 219.3 & 219.4 \\
\hline Solid components & 1:1 PE/FA & 1:1 PE/FA & 1:1 PE/FA & $\mathrm{PE}$ & 1:1 PE/PN \\
\hline Mass of solids, $\mathrm{g}$ & 114.5 & 114.2 & 114.5 & 52.0 & 103.8 \\
\hline Temperature, $\mathrm{K}$ & 308 & 342 & 363 & 342 & 342 \\
\hline
\end{tabular}

The second series, designated SII, involved the synthesis of four geopolymers based on liquid components: 8 $\mathrm{mol} / \mathrm{dm}^{3}$ solution of $\mathrm{NaOH}$ and sodium water glass in a 1:2 mass ratio, and solid components: expanded perlite or a mixture of expanded perlite with fly ash in a 1:1 mass ratio. The conditions and formula used for the synthesis are presented in Table 3 below. 
Table 3

Substrates and conditions for geopolymer synthesis based on $\mathrm{NaOH}$ : SIl series.

\begin{tabular}{|c|c|c|c|c|}
\hline Sample data & SIl 1 & SII 2 & SII 3 & SII 4 \\
\hline $\begin{array}{l}\text { Liquid } \\
\text { components }\end{array}$ & $\begin{array}{l}1: 2 \\
\mathrm{NaOH} / \mathrm{SWG}\end{array}$ & $\begin{array}{l}1: 2 \\
\mathrm{NaOH} / \mathrm{SWG}\end{array}$ & $\begin{array}{l}1: 2 \\
\mathrm{NaOH} / \mathrm{SWG}\end{array}$ & $\begin{array}{l}1: 2: 0.036 \\
\mathrm{NaOH} / \mathrm{SWG} / \mathrm{H}_{2} \mathrm{O}_{2}\end{array}$ \\
\hline Mass of liquids, $\mathrm{g}$ & 226.6 & 227.7 & 226.6 & 236.8 \\
\hline Solid components & 1:1 PE/FA & 1:1 PE/FA & 1:1 PE/FA & PE \\
\hline Mass of solids, $\mathrm{g}$ & 114.2 & 114.2 & 114.2 & 57.1 \\
\hline Temperature, $\mathrm{K}$ & 308 & 342 & 363 & 342 \\
\hline
\end{tabular}

\subsection{Geopolymer synthesis}

The synthesis of nine geopolymers was performed, including six materials based on fly ash from a power generation unit situated in Poland, powered by lignite, and three materials based on expanded and nonexpanded perlite and their mixtures.

The adopted methodology for sample synthesis consisted of substrate mixing, a 5-minute (min.) stabilization in a shaker, casting of samples in a special normalized mould and curing at temperatures from 308 to $362 \mathrm{~K}$. Two series of experiments were planned and performed. The liquid ingredients SI series were introduced into the vessel first, at room temperature, and the solids were added gradually while stirring with a glass stirrer in order to obtain a uniform, liquid mixture. Then, the mixture was placed in a shaker for $5 \mathrm{~min}$. to stabilize the sample volume and then placed into the mould. The geopolymers were placed in a furnace heated to 308,342 or $363 \mathrm{~K}$ for 24 hours. The processes of substrate mixing, compaction and annealing in the SII series were performed in the same way as in the SI series. Only expanded perlite was added to the mixture containing solids at the end of mixing (one hour after the beginning) at $1 \%$ by weight of $\mathrm{H}_{2} \mathrm{O}_{2}$.

The formula included potassium and sodium alkaline activators. The effect of the addition of expanded and non-expanded perlite and $\mathrm{H}_{2} \mathrm{O}_{2}$ on the synthesis of geopolymers and the resulting changes in the properties of the obtained geopolymer concretes, were also investigated.

\section{Measurement Methods}

\subsection{Thermal conductivity}

Measurements of the thermal conductivity were taken with the Fox 50 device with heat flux sensors in a symmetrical arrangement according to PN-ISO 8301:1998, at an average test temperature of $283 \mathrm{~K}$ and at dT $=10$. The measurement was performed on cylindrical samples with a diameter of $60 \mathrm{~mm}$ and $60 \mathrm{~mm}$ high.

\subsection{Refractoriness}


Refractoriness (ordinary fire resistance) illustrates the materials' durability at high temperatures. It is the approximate melting temperature of a given material, i.e., the temperature at which a cone of the size specified in the standard PN-EN 993 - 12:2000. Methods of test for dense shaped refractory products - part 12: determination of pyrometric cone equivalent (refractoriness), made of the tested material touches the base with its folded top. The refractoriness is determined in the SP scale by the standard. However, there is no traditional international equivalent of this parameter. The SP value multiplied by 10 gives the approximate melting temperature of the given material in Celsius degrees ("PN-EN 993 - 12:2000 - Refractory materials Test methods for compact, formed and informal refractory products - Determination of equivalent pyrometric cone (ordinary fire resistance)," 2000).

\subsection{Compression-strength tests}

After 28 days the materials obtained were subjected to compression-strength tests using a Matest Cyber-Plus Evolution apparatus ("PN-EN 12390-3:2011, Concrete testing - Part 3: Compressive strength of test pieces," 2011) and fire-resistance tests according to the standard PN-EN $993-12: 2000$. The values of thermal conductivity coefficients were determined using an ISOMET 2114 instrument.

\subsection{Porosimetry}

The mercury porosimetry methods were employed to determine the volume and surface of pores in the investigated geopolymer samples. Porosimetric measurements were conducted with the Pascal 140 and Pascal 440 porosimeters (CE Instruments ThermoQuest). In mercury porosimetry methods, the pores of the investigated material are penetrated by mercury under pressure. Mercury porosimetry is capable of handling a wide range of pores, including macropores and mesopores. This method is widely used for measuring the macroporosity of porous substances and can be employed in measurements of some mesopores, the pore size range depending on the pressure generated by the porosimeter and the sample resistance.

\subsection{Real density}

Geopolymer density was measured with the Accu Pyc Micrometrics 1330 device. The use of helium makes it possible to study porous media or media with an intrinsic surface structure. As a noble gas, helium does not interact with other substances, does not get adsorbed neither at ambient temperature nor at elevated temperatures and its molecule is really small. That is why the use of helium allows to penetrate even the smallest pores, so the sample volume and density can be precisely determined.

\subsection{Microscopy.}

Microscopic images have been obtained with the VHX-7000 series by KEYENCE America optical digital microscope. High-resolution images show the smallest details. A specialized design with high-resolution lenses, $4 \mathrm{~K}$ CMOS sensor and lighting technology was used in order to create an optical shadow effect.

\section{Experiment Results}

From the results presented in Tables 4 and 5 it is visible that compressive strength values in both series are similar. In each series, there is one sample of higher value (above 4). It should be underlined that refractoriness, for the majority of samples is higher than 1000 . 
In Figs. 3 and 4 there were presented the macroscopic pictures of series SI and SII respectively.

Table 4

Properties of the materials obtained: SI series (samples activated by potassium hydroxide).

\begin{tabular}{|llllll|}
\hline Quantity & SI1 & SI2 & SI3 & SI4 & SI5 \\
& $\mathbf{( 3 0 8 K )}$ & $\mathbf{( 3 4 2 K )}$ & $\mathbf{( 3 6 3 K )}$ & $\mathbf{( 3 4 2 K )}$ & $\mathbf{( 3 4 2 K )}$ \\
\hline Compressive strength, MPa & 4.901 & 2.018 & 1.375 & 2.968 & 2.524 \\
\hline Refractoriness, ${ }^{\circ} \mathrm{C}$ & $\mathrm{SP}>1200$ & $\mathrm{SP}>1200$ & $\mathrm{SP}>1200$ & 1000 & 1000 \\
\hline Thermal conductivity, W/m·K & 0.207 & 0.207 & 0.197 & 0.108 & 0.136 \\
\hline
\end{tabular}

Table 5

Properties of the materials obtained: SIl series (samples activated by sodium hydroxide).

\begin{tabular}{|lllll|}
\hline Quantity & SII 1 & SII 2 & SII 3 & SII 4 \\
& $(\mathbf{3 0 8 K})$ & $\mathbf{( 3 4 2} \mathrm{K})$ & $\mathbf{( 3 6 3 K )}$ & $\mathbf{( 3 4 2 K )}$ \\
\hline Compressive strength, $\mathrm{MPa}$ & 4.984 & 1.935 & 1.350 & 2.238 \\
\hline Refractoriness, ${ }^{\circ} \mathrm{C}$, & 1000 & 1050 & 1100 & 850 \\
\hline Thermal conductivity, $\mathrm{W} / \mathrm{m} \cdot \mathrm{K}$ & 0.232 & 0.160 & 0.194 & 0.086 \\
\hline
\end{tabular}

Results of densimetric tests for both series are shown in Tables 6 and 7 below.

Table 6

Results of densimetric tests for SI samples

\begin{tabular}{|llllll|}
\hline Sample & SI1 & SI2 & SI3 & SI4 & SI5 \\
\hline Total porosity [\%] & 23.68 & 16.19 & 27.92 & 41.84 & 30.76 \\
\hline Bulk density $[\mathrm{g} / \mathrm{cm} 3]$ & 1.1780 & 1.0222 & 0.8819 & 0.7673 & 1.0889 \\
\hline Apparent density $[\mathrm{g} / \mathrm{cm} 3]$ at $101.3[\mathrm{kPa}]$ & 1.6599 & 1.4712 & 1.3919 & 0.8018 & 1.4366 \\
\hline Apparent density $[\mathrm{g} / \mathrm{cm} 3]$ at $150[\mathrm{MPa}]$ & 2.2329 & 1.8880 & 2.0010 & 1.3905 & 2.1255 \\
\hline Helium density $[\mathrm{g} / \mathrm{cm} 3]$ & 2.0980 & 2.2913 & 2.1867 & 1.6800 & 2.2855 \\
\hline
\end{tabular}


Table 7

Results of densimetric tests for SII samples

\begin{tabular}{|lllll|}
\hline Sample & SII1 & SII2 & SII3 & SII4 \\
\hline Total porosity [\%] & 44.12 & 60.47 & 44.26 & 22.16 \\
\hline Bulk density $[\mathrm{g} / \mathrm{cm} 3]$ & 0.8829 & 0.9924 & 0.9965 & 1.3730 \\
\hline Apparent density $[\mathrm{g} / \mathrm{cm} 3]$ at $101.3[\mathrm{kPa}]$ & 1.0673 & 1.0242 & 1.4141 & 1.8623 \\
\hline Apparent density $[\mathrm{g} / \mathrm{cm} 3]$ at $150[\mathrm{MPa}]$ & 2.6133 & 2.5908 & 2.5370 & 2.3971 \\
\hline Helium density $[\mathrm{g} / \mathrm{cm} 3]$ & 2.1979 & 2.0378 & 2.1387 & 2.1184 \\
\hline
\end{tabular}

All density parameters, bulk density, apparent density at $101.3 \mathrm{kPa}$ and apparent density at $150 \mathrm{MPa}$ are apparent densities, only the pore size which has been included in calculations, differs:

- bulk density - takes into consideration the skeleton volume, including pores of $<58000 \mathrm{~nm}$ radius,

- apparent density $(101,3 \mathrm{kPa})$ - takes into consideration the skeleton volume, including pores of $<7500$ nm radius,

- apparent density (150 MPa) - takes into consideration the skeleton volume, including pores of $<5 \mathrm{~nm}$ radius, smaller pores are free, bigger filled with $\mathrm{Hg}$ at a given pressure.

The results of porosimetric analyses show that the sample synthesis preparation (individual mixture composition) significantly influences textural parameters (share for each range, total pore volume in the analyzed range $58000 \mathrm{~nm}-5 \mathrm{~nm})$.

Refractoriness is determined using the sP scale. The sP value multiplied by 10 gives the approximate melting temperature of the material, measured in Celsius degrees, but it has no traditional international equivalent. This is why we give the parameter values as the melting/fusion temperature in Celsius degrees. Also the thermal conductivity in each series, presents one value that is beyond the average ranges. The refractoriness of the obtained geopolymers is satisfactory. It is too low to classify these materials as refractory (from $1580^{\circ} \mathrm{C}$ ), but higher than the refractoriness of concrete (about $600^{\circ} \mathrm{C}$ ). Figures 3 and 4 present macroscopic pictures of the samples illustrating some morphological differences between the samples. Similarly, it is shown below in the photographs taken by an optical digital microscope, Figs. 6 and 7 .

\section{Discussion}

For all analyzed samples, mostly the pores are above $1000 \mathrm{~nm}$. The observed increase of porosity in the range below $10 \mathrm{~nm}$ is most likely falsified due to the compressibility of the material itself. In samples 1-3 (both series, SI and SII) obtained in the same procedure but differing in curing temperature and type of activating agent, some differences can be observed. For the lowest curing temperature, the $\mathrm{KOH}$ activated sample (SI1) has almost twice the total pore volume compared to the $\mathrm{NaOH}$ activated sample (SII1). At the highest curing temperature (363K) these differences disappear (Fig. 5) regardless of the activating agent, the porosity of the samples is similar (SI3 and SII3). 
The SI series showed an increase in thermal conductivity that was proportional to the share of solid components in the mixture. This doubles over the series of geopolymers SI2, SI4 and SI5. A similar relationship exists in the SII series for geopolymers cured at the same temperature of $342 \mathrm{~K}$. The value of the thermal conductivity almost doubles here, in the series of geopolymers from SII4 to SII2.

No dependence of the thermal conductivity on the curing temperature of geopolymers in the $\mathrm{SI}$ series $(0.20$ $\mathrm{W} / \mathrm{m} \cdot \mathrm{K}$ for SI3, SI4 and SI5), was observed. However, in the case of the SII series (SII1, SII2 and SII3), fluctuations in the value within a range of $35 \%$ of the aforementioned average value for the SI series, were observed. The SI and SII series enable comparisons of geopolymer samples with identical proportions of solid and liquid components and identical curing temperatures (308 K - SI1/SII1, $342 \mathrm{~K}-\mathrm{SI} 2 / \mathrm{SII} 2$ and $363 \mathrm{~K}-$ $\mathrm{SI3/SII3),} \mathrm{but} \mathrm{with} \mathrm{different} \mathrm{K}^{+} / \mathrm{Na}^{+}$active metal ions used in the synthesis. It is likely that in the SII group based on $\mathrm{Na}^{+}$, the porous geopolymer structure of the geopolymer was different at different temperatures as a result of the type and number of gas bubbles formed.

The effect of the ion type (potassium/sodium) on the geopolymer thermal conductivity value is shown in Fig. 8 presenting the change in thermal conductivity with an increasing share of solid components in the reaction mixture $X_{s}$.

Regardless of the mixture composition, the thermal conductivity of the SI series geopolymers containing potassium ions is higher than in the SIl series geopolymers containing sodium ions. The K-curve values for the SI series are $20 \%$ higher than those for the SII series. The lowest thermal conductivity values can be expected for geopolymers containing $\mathrm{Na}$ ions with a low content of solid ingredients $\mathrm{Xs}$ in the mixture.

The following figure, Fig. 9 shows the changes of compressive strength with increasing proportion of solid components in the reaction mixture. It can be seen that regardless of the mixture composition, the compressive strength of the SI series geopolymers containing potassium ions is higher than SII series geopolymers containing sodium ions. The differences for geopolymers of equal reaction mixture composition decrease from 33 to $17 \%$ with the increase of the Xs fraction. Therefore, the highest compressive strength should be expected for geopolymers containing potassium ions and with a low content of solid components in the reaction mixture.

As shown in Fig. 10, the thermal conductivity value of SI and SII series geopolymers does not depend on the curing temperature of the mixture. Therefore, it is possible to distinguish the effect of non-expanded perlite and fly ash additions. As mentioned before, the reference geopolymer for comparison is the SI4 containing only expanded perlite. The addition of non-expanded perlite increases the thermal conductivity by $26 \%$ and the thermal conductivity values of geopolymers containing fly ash is on average $90 \%$ higher.

The opposite effect (Fig. 10) on thermal conductivity is caused by adding $\mathrm{H}_{2} \mathrm{O}_{2}$, foaming agent, during the geopolymer curing. The thermal conductivity of the SI4 reference geopolymer is by $26 \%$ higher in comparison with the SII4 polymer with the addition of $\mathrm{H}_{2} \mathrm{O}_{2}$. The conductivity coefficient of this geopolymer is close to the value for pure expanded perlite, which is $0.05 \mathrm{~W} / \mathrm{m} \mathrm{K}$. Its cause, as can be assumed, is the formation of the material's cellular structure containing gas bubbles, formed during the $\mathrm{H}_{2} \mathrm{O}_{2}$ decomposition during the material curing. 
Taking into account the influence of the share of solid components in the mixture and the type of active metal ion used in the synthesis, the geopolymers with the best thermal insulation properties can be found in the SII group. This can also be seen in Fig. 10, where the points for the SII series are shifted in the direction of lower values of the conductivity coefficient, compared to the SI series. This is confirmed by the SII4 geopolymer (Table 5), which has the lowest share of solid components by mass in the SII group, equivalent to the SI4 geopolymer but with an increased number of gas bubbles due to $\mathrm{H}_{2} \mathrm{O}_{2}$ addition. The thermal conductivity coefficient for SII4 is similar to that for pure expanded perlite $(0.05 \mathrm{~W} / \mathrm{m} \cdot \mathrm{K} ; \mathrm{Fig} .10)$ and lower than that for expanded concrete blocks $(0.17 \mathrm{~W} / \mathrm{m} \cdot \mathrm{K})$ (“Technical Sheet - keramzit brick," n.d.)

The value of the thermal conductivity of an external wall of a building for six of the nine geopolymers (Table 4 and Table 5) with $8 \mathrm{~cm}$ of polystyrene foam insulation, is lower than the permissible thermal conductivity for external walls of buildings ( $\mathrm{Uc}(\max )$ ) of $0.2 \mathrm{~W} / \mathrm{m}^{2} \cdot \mathrm{K}$ by the Journal of Laws, 2017, paragraph 2285 (Regulation of the Minister of Infrastructure and Construction of 14 November 2017 amending the Regulation on technical conditions to be met by buildings and their location., 2017). This means that they fully meet the requirements for thermal insulation of external building walls in Poland. Geopolymers SI3, SI4, SI5, SII2, SII3 and SII4 meet these conditions, and three of these include fly ash as one of the mixture components.

Compressive strength values $(\sigma)$ in both series of experiments show a strong dependence on the curing temperature of the geopolymer. $\sigma$ increases 3.6 times in the series SI1, SI2 and SI3, inversely proportionally to the curing temperature. Similarly, in the SII-series geopolymers, the increase in strength is 3.7 times in the series SII1, SII2 and SII3, where there is a decrease in the curing temperature from 363 to $308 \mathrm{~K}$.

The points of the two series SI and SII can also be matched with satisfactory accuracy using the common relationship shown in Fig. 11.

The compression strength values of two of the obtained materials, the SI1 and SII1, correspond to the 3.5 strength class for ceramic wall elements such as grid brick and hollow brick, and five of the geopolymers, the SI2, SI4, SI5, SII2, SII3 and SII4, correspond to the 1.5 strength class, pertinent with the values for hollow ceramic partition bricks. These are also similar to values typical for porous ceramic elements of walls, such as foam concrete or keramzit concrete ("Technical Sheet - keramzit brick," n.d.).

In addition to the aforementioned increase in thermal conductivity, the higher the solid component content in geopolymer blends, the lower their compression strength. Similar results have been reached by Baran et. al. (Baran et al., 2021). A decrease in the $\sigma$ value is observed both in the case of the addition of non-expanded perlite (at 25\% for SI5) and in the case of addition of fly ash (at 32\% for SI2), compared to the SI4 sample. However, the influence of this factor was almost 10 times lower than the influence of the curing temperature of the geopolymer. The $\sigma$ strength of the SI2 geopolymer was therefore 20 times higher than that of EPS 100, used for insulation of longitudinal and wall surfaces exposed to high loads and impacts, and three times higher than that of XPS 70 panels, used for insulation of airport slabs, bridges and roads ("Technical Sheet Synthos XPS PRIME," 2013).

In both series, SI and SII, the influence of the fly ash additive on the increase in geopolymer refractory properties is clear. The highest values characterize geopolymers containing fly ash as one of the components 
of the mixture (SI1-3 and SII1-3). However, this increase is more pronounced in the SI series based on the $\mathrm{K}^{+}$ ions, which can be observed by comparing individual geopolymers with the addition of ash (308 K - SI1/SII1, $342 \mathrm{~K}-\mathrm{SI} / \mathrm{SII} 2$ and $363 \mathrm{~K}-\mathrm{SI} / \mathrm{SII} 3$ ) and without it (342 K - SI4/SII4) (Table 4 and Table 5). The fireresistance values of the geopolymers in this series, with the addition of ash, are analogous to those of chamotte ("Fenixus S.C.," 2020). The thermal resistance of all geopolymers, however, were similar these of typical materials used for thermal insulation of stoves or fireplaces.

Fly ash, which accounts for more than $5 \%$ of CCPs from the energy industry, can be used as a substrate in the production of geopolymer materials used in construction. Their production technology also reduces $\mathrm{CO}_{2}$ emissions from the production of Portland cement, which is compatible with both the circular economy ("IEA. Market Report Series: Coal 2018," 2018; Sauvé et al., 2016) and the implementation of clean coal technologies (Xu et al., 2017).

\section{Conclusion}

The obtained materials have low thermal conductivity values, similar to those of pure expanded perlite, which place them within the group of insulating materials. The SII4 geopolymer fully meets the requirements for refractoriness in Poland, to be used for single-layer walls. Other SI- and SII-series geopolymers are competitive in this respect with currently used ceramic wall materials used for double-layer external walls.

Of the two variables analyzed in this study, i.e., the influence of the mixture composition on the synthesis and the curing temperature of the geopolymer, only the first one had a significant influence on the value of the heat conduction coefficient. A similar, proportional dependence of the $\mathrm{K}$ coefficient on the mass share of solid components of the mixture in the synthesis, was observed for both series of experiments. However, these values were lower in the SIl series based on $\mathrm{Na}^{+}$.

The obtained geopolymers can be classified as strength class 3.5 or 1.5 for wall materials, hollow partition bricks or porous ceramic elements, and within the group of insulation materials, they exceed the strength of materials with the highest strength parameters, used for the insulation of roads, airports or bridges. The strength of the obtained geopolymers largely depends on their curing temperature. This inversely proportional dependence of strength and temperature can be described for all series of experiments with good accuracy, using the common function presented in Fig. 11.

The addition of fly ash increases the refractoriess value of the products. The materials obtained are comparable to chamotte in this respect and can be successfully used for insulating stoves and fireplaces.

\section{Declarations}

Author Contributions: Conceptualization: Paweł Baran and Katarzyna Zarębska; methodology: Piotr Zabierowski, Paweł Baran, Katarzyna Zarębska; validation: Paweł Baran, Katarzyna Zarębska, Natalia Czuma; formal analysis: Piotr Zabierowski, Paweł Baran, Katarzyna Zarębska; investigation: Piotr Zabierowski; resources: Natalia Czuma, Paweł Baran; data curation: Natalia Czuma, Paweł Baran and Katarzyna Zarębska; writing-original draft preparation: Magdalena Gazda-Grzywacz, Piotr Zabierowski; writing-review and 
editing: Natalia Czuma, Magdalena Gazda-Grzywacz, Piotr Zabierowski, Paweł Baran and Katarzyna Zarębska; visualization: Natalia Czuma, Paweł Baran, Magdalena Gazda-Grzywacz; supervision: Katarzyna Zarębska, Paweł Baran; project administration: Katarzyna Zarębska; funding acquisition: Katarzyna Zarębska. All authors have read and agreed to the published version of the manuscript.

Funding: This research was funded by AGH University of Science and Technology in Krakow, Poland, grant number 16.16.210.476.

Conflicts of Interest:The authors declare no conflict of interest.

\section{References}

1. Baran, P., Nazarko, M., Włosińska, E., Kanciruk, A., Zarębska, K., 2021. Synthesis of geopolymers derived from fly ash with an addition of perlite. J. Clean. Prod. 293.

https://doi.org/10.1016/j.jclepro.2021.126112

2. Baran, P., Zarebska, K., Kanciruk, A., Nazarko, M., Obal, M., 2017. Effect of synthesis parameters on the compressive strength of geopolymers obtained from fly ashes. Przem. Chem. 96, 1923-1926. https://doi.org/10.15199/62.2017.9.21

3. Bubshait, A.A., Tahir, B.M., Jannadi, M.O., 1996. Use of microsilica in concrete construction. Build. Res. Inf. 24, 41-49. https://doi.org/10.1080/09613219608727497

4. Çelik, P.A., Aksoy, D.Ö., Koca, S., Koca, H., Çabuk, A., 2019. The approach of biodesulfurization for clean coal technologies: a review. Int. J. Environ. Sci. Technol. 16, 2115-2132. https://doi.org/10.1007/s13762-019-02232-7

5. Central Statistical Office, Environmental Protection, 2019. . Warsaw.

6. Central Statistical Office, GUS, Energy, 2019. . Warsaw.

7. Cheng, T.W., Chiu, J.P., 2003. Fire-resistant geopolymer produced by granulated blast furnace slag. Miner. Eng. 16, 205-210. https://doi.org/10.1016/S0892-6875(03)00008-6

8. Communication from the Commission to the European Parliament, the Council, the European Economic and Social Committee and the Committee of the Regions Towards a closed-loop economy: the zero-waste programme for Europe, 2014. . Brussels.

9. Crossin, E., 2012. Comparative Life Cycle Assessment of Concrete Blends. https://doi.org/10.13140/RG.2.1.3644.3683

10. Duxson, P., Fernández-Jiménez, A., Provis, J.L., Lukey, G.C., Palomo, A., van Deventer, J.S.J., 2007. Geopolymer technology: the current state of the art. J. Mater. Sci. 42, 2917-2933. https://doi.org/10.1007/s10853-006-0637-z

11. Erkman, S., 1997. Industrial ecology: An historical view. J. Clean. Prod. 5, 1-10. https://doi.org/https://doi.org/10.1016/S0959-6526(97)00003-6

12. Fenixus S.C. [WWW Document], 2020. URL http://betonyogniotrwale.pl/index.php?go=wyrobyizolacyjne (accessed 3.20.20). 
13. Giesekam, J., Barrett, J.R., Taylor, P., 2016. Construction sector views on low carbon building materials. Build. Res. Inf. 44, 423-444. https://doi.org/10.1080/09613218.2016.1086872

14. IEA. Market Report Series: Coal 2018 [WWW Document], 2018. . Int. Energy Agency. URL www.iea.org/coal

15. Kasztelewicz, Z., Polak, K., Zajączkowski, M., 2009. The Possibilities of implementing clean coal technologies in the brown coal industry in Poland. AGH J. Min. Geoengin. 33, 233-240.

16. Koleżyński, A., Król, M., Żychowicz, M., 2018. The structure of geopolymers - Theoretical studies. J. Mol. Struct. 1163, 465-471. https://doi.org/https://doi.org/10.1016/j.molstruc.2018.03.033

17. Kumar, S., Kumar, R., 2011. Mechanical activation of fly ash: Effect on reaction, structure and properties of resulting geopolymer. Ceram. Int. 37, 533-541.

https://doi.org/https://doi.org/10.1016/j.ceramint.2010.09.038

18. Lieder, M., Rashid, A., 2016. Towards circular economy implementation: a comprehensive review in context of manufacturing industry. J. Clean. Prod. 115, 36-51.

https://doi.org/https://doi.org/10.1016/j.jclepro.2015.12.042

19. Ma, C.-K., Awang, A.Z., Omar, W., 2018. Structural and material performance of geopolymer concrete: A review. Constr. Build. Mater. 186, 90-102.

https://doi.org/https://doi.org/10.1016/j.conbuildmat.2018.07.111

20. Naik, T., 2008. Sustainability of Concrete Construction. Pract. Period. Struct. Des. Constr. 13. https://doi.org/10.1061/(ASCE)1084-0680(2008)13:2(98)

21. Paprocki, A., Oyrzanowski, S., 1975. Hydraulic activation of fly ash for concrete. Batim. Int. Build. Res. Pract. 3, 182. https://doi.org/10.1080/09613217508550390

22. Parshwanath, R., Nataraja, M., Lakshmanan, N., 2011. An introduction to geopolymer concrete. Indian Concr. J. 85, 25-28.

23. PCA, Polish Cement Association. CO2 changes the face of the cement industry, 2019. . Kraków.

24. Perumal, P., Piekkari, K., Sreenivasan, H., Kinnunen, P., Illikainen, M., 2019. One-part geopolymers from mining residues - Effect of thermal treatment on three different tailings. Miner. Eng. 144, 106026. https://doi.org/https://doi.org/10.1016/j.mineng.2019.106026

25. Pires, A., Martinho, G., 2019. Waste hierarchy index for circular economy in waste management. Waste Manag. 95, 298-305. https://doi.org/https://doi.org/10.1016/j.wasman.2019.06.014

26. PN-EN 12390-3:2011, Concrete testing - Part 3: Compressive strength of test pieces, 2011.

27. PN-EN 993-12:2000 - Refractory materials - Test methods for compact, formed and informal refractory products - Determination of equivalent pyrometric cone (ordinary fire resistance), 2000.

28. Provis, J.L., Bernal, S.A., 2014. Geopolymers and Related Alkali-Activated Materials. Annu. Rev. Mater. Res. 44, 299-327. https://doi.org/10.1146/annurev-matsci-070813-113515

29. Rattanasak, U., Chindaprasirt, P., 2009. Influence of $\mathrm{NaOH}$ solution on the synthesis of fly ash geopolymer. Miner. Eng. 22, 1073-1078.

https://doi.org/https://doi.org/10.1016/j.mineng.2009.03.022

30. Regulation of the Minister of Infrastructure and Construction of 14 November 2017 amending the Regulation on technical conditions to be met by buildings and their location., 2017. . Poland. 
31. Rosiek, J., 2018. The implementation of Circular Economy Concept in the Polish Coal Combustion Products Sector - selected problems. Econ. Environ. Stud. 18, 353-373.

https://doi.org/10.25167/ees.2018.45.20

32. Salas, D.A., Ramirez, A.D., Ulloa, N., Baykara, H., Boero, A.J., 2018. Life cycle assessment of geopolymer concrete. Constr. Build. Mater. 190, 170-177.

https://doi.org/https://doi.org/10.1016/j.conbuildmat.2018.09.123

33. Sathish, M., Madhan, B., Raghava Rao, J., 2019. Leather solid waste: An eco-benign raw material for leather chemical preparation - A circular economy example. Waste Manag. 87, 357-367. https://doi.org/https://doi.org/10.1016/j.wasman.2019.02.026

34. Sauvé, S., Bernard, S., Sloan, P., 2016. Environmental sciences, sustainable development and circular economy: Alternative concepts for trans-disciplinary research. Environ. Dev. 17, 48-56. https://doi.org/https://doi.org/10.1016/j.envdev.2015.09.002

35. Stopińska, W.J., 2015. Utilization of anthropogenic minerals from power industry and heat engineering - circular economy project [WWW Document]. URL kne.itc.pw.edu.pl /attachments/article/154/WiolettaStopińska.pdf (accessed 7.10.19).

36. Technical Sheet - Synthos XPS PRIME [WWW Document], 2013. URL www.termodek.pl /img/TDS_SYNTHOS_XPS_PRIME_30_PL.pdf (accessed 3.20.21).

37. Technical Sheet - keramzit brick [WWW Document], n.d. URL http://www.cjblok.com.pl/cms /upload/file/PK12.pdf (accessed 7.2.20).

38. Teixeira, E.R., Camões, A., Branco, F.G., Aguiar, J.B., Fangueiro, R., 2019. Recycling of biomass and coal fly ash as cement replacement material and its effect on hydration and carbonation of concrete. Waste Manag. 94, 39-48. https://doi.org/https://doi.org/10.1016/j.wasman.2019.05.044

39. Vaičiukynienė, D., Michalik, B., Bonczyk, M., Vaičiukynas, V., Kantautas, A., Krulikauskaitè, J., 2018. Zeolitized bottom ashes from biomass combustion as cement replacing components. Constr. Build. Mater. 168, 988-994. https://doi.org/https://doi.org/10.1016/j.conbuildmat.2018.02.057

40. Van Deventer, J.S.J., Provis, J.L., Duxson, P., 2012. Technical and commercial progress in the adoption of geopolymer cement. Miner. Eng. 29, 89-104. https://doi.org/https://doi.org/10.1016/j.mineng.2011.09.009

41. Vaou, V., Panias, D., 2010. Thermal insulating foamy geopolymers from perlite. Miner. Eng. 23, 11461151. https://doi.org/10.1016/j.mineng.2010.07.015

42. Xu, X., Liu, Y., Zhang, F., Di, W., Zhang, Y., 2017. Clean coal technologies in China based on methanol platform. Catal. Today 298, 61-68. https://doi.org/https://doi.org/10.1016/j.cattod.2017.05.070

43. Yang, K.-H., Song, J.-K., Song, K.-I., 2013. Assessment of CO2 reduction of alkali-activated concrete. J. Clean. Prod. 39, 265-272. https://doi.org/https://doi.org/10.1016/j.jclepro.2012.08.001

44. Zarębska, K., Klima, K., Złotkowski, A., Kamienowska, M., Czuma, N., Baran, P., 2019. Synthesis of geopolymers by using blast furnace slag. Przem. Chem. 98. https://doi.org/10.15199/62.2019.2.23

\section{Figures}




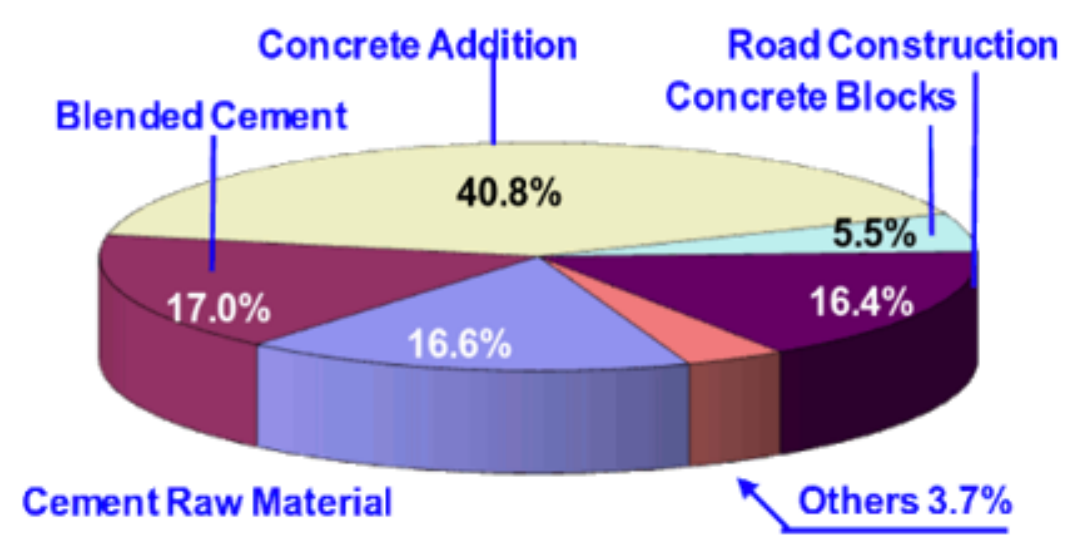

Figure 1

Utilization of fly ash in the construction industry and underground mining in Europe (EU) in 2016 (access: 02.02.2021 http://www.ecoba.com/ecobaccputil.html)

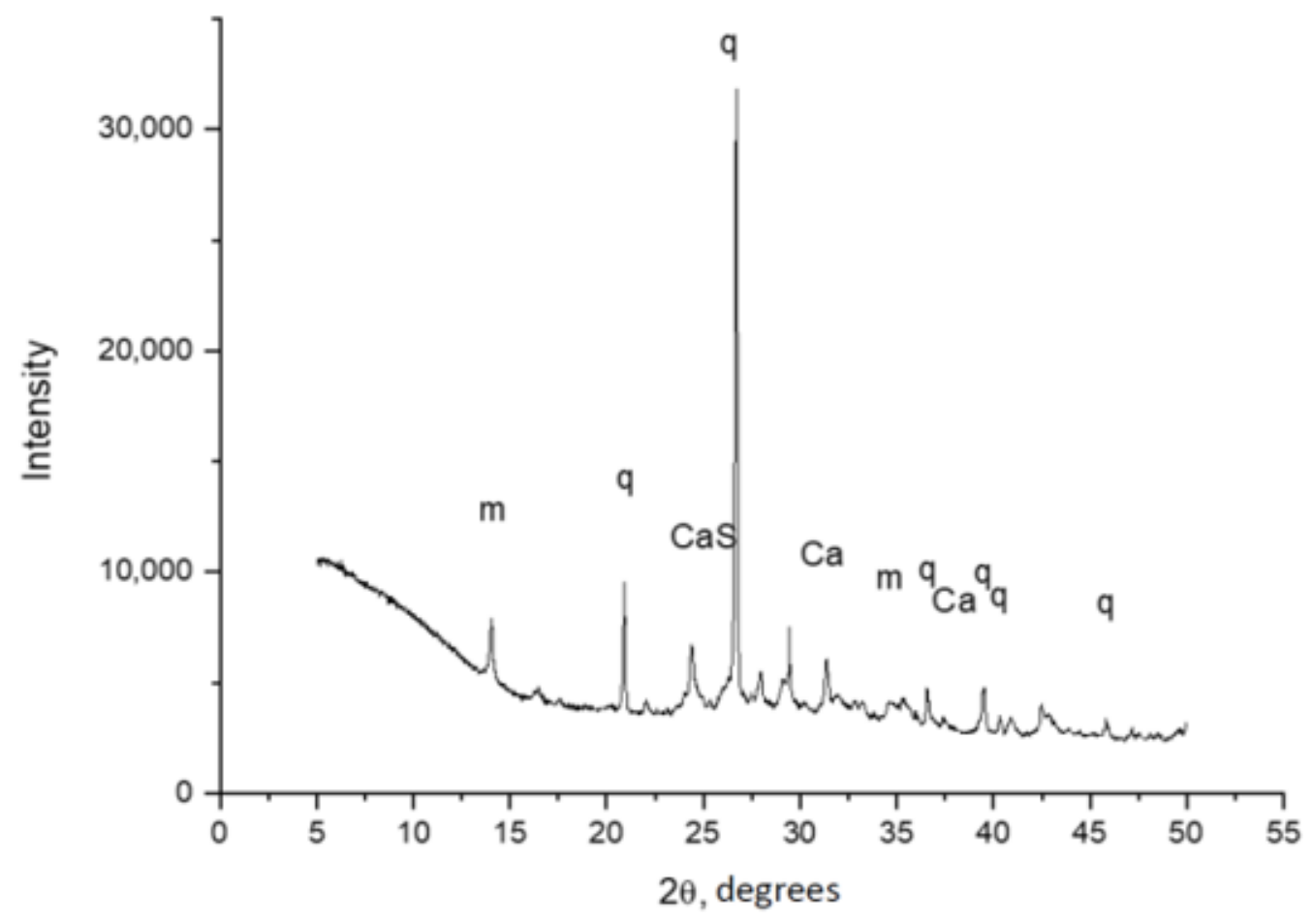

Figure 2

Fly ash diffractogram (q: quartz, m: mullite, Ca: calcium carbonate, CaS: calcium sulphate). 


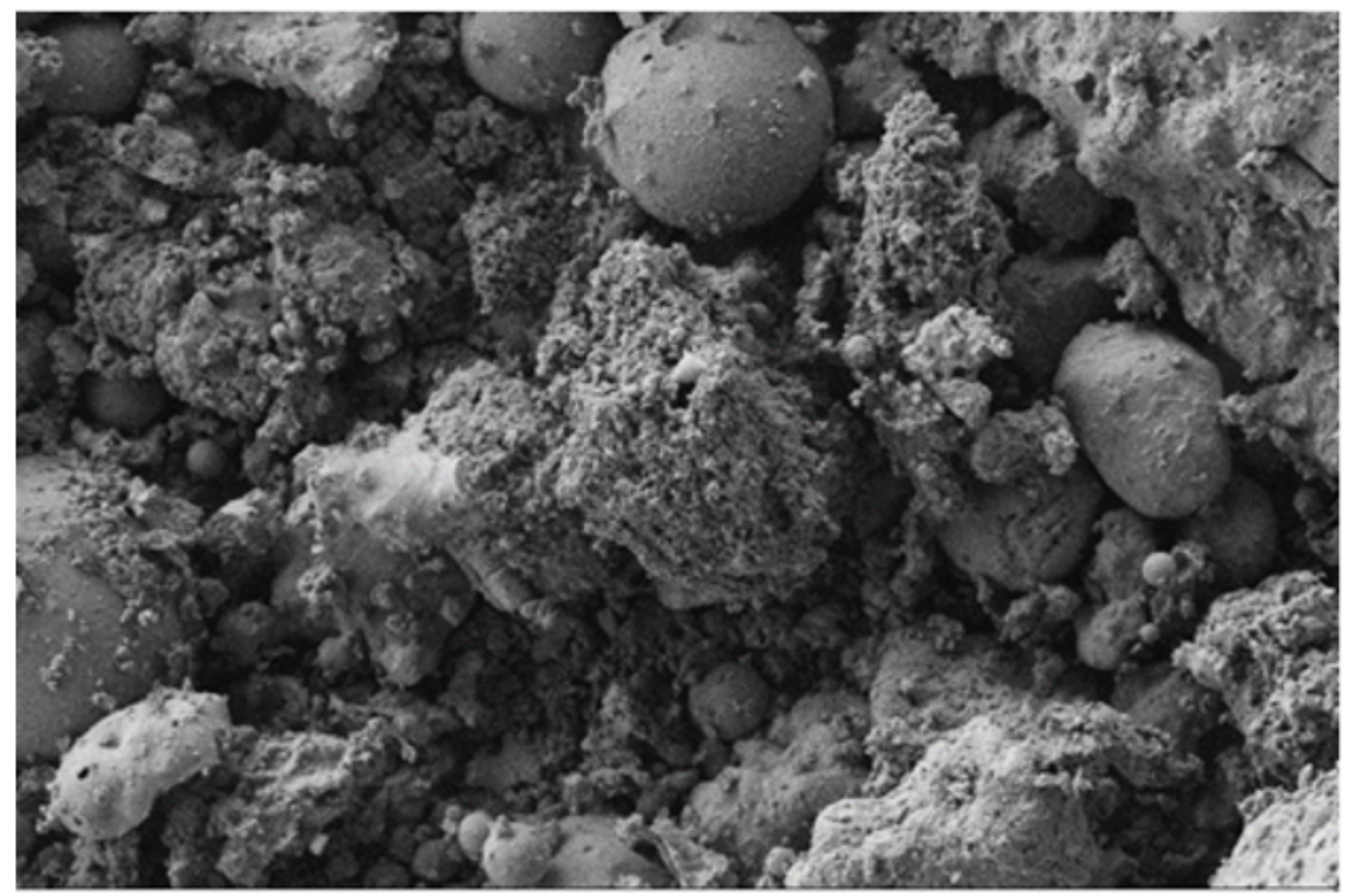

\section{Figure 3}

SEM microphotograph of fly ash, magnification: 5000x.
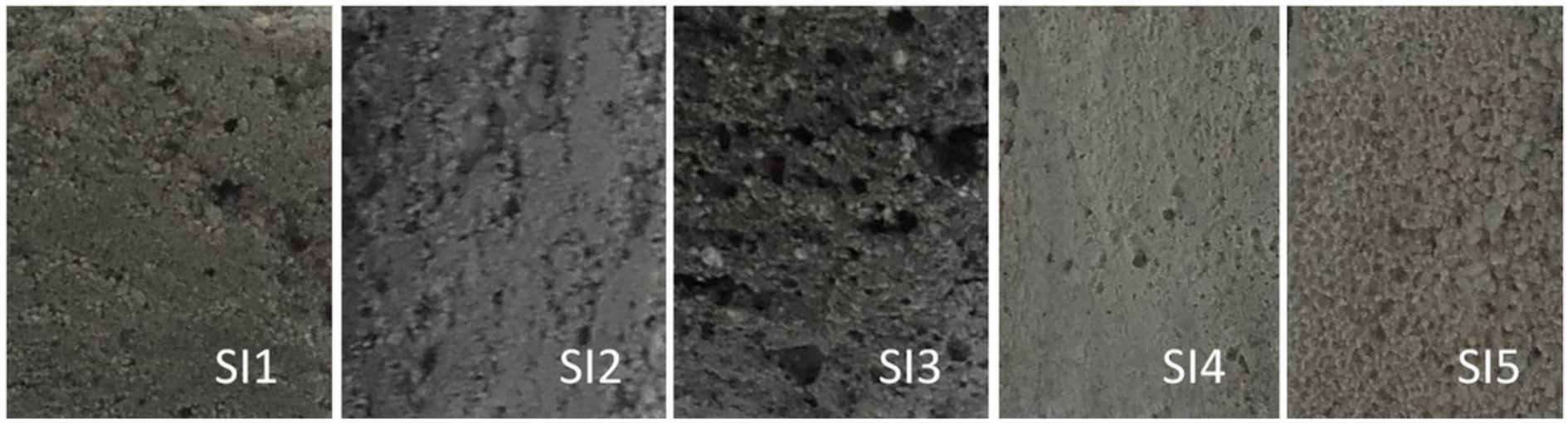

\section{Figure 4}

Macroscopic pictures of the SI series. 

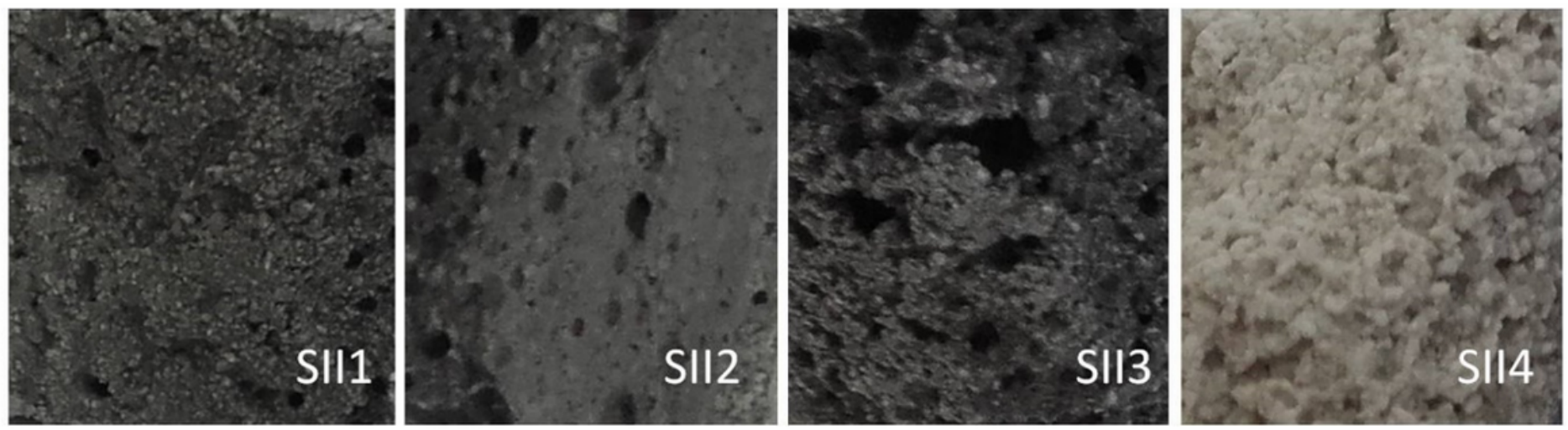

\section{Figure 5}

Macroscopic pictures of the SII series.

SI

SII
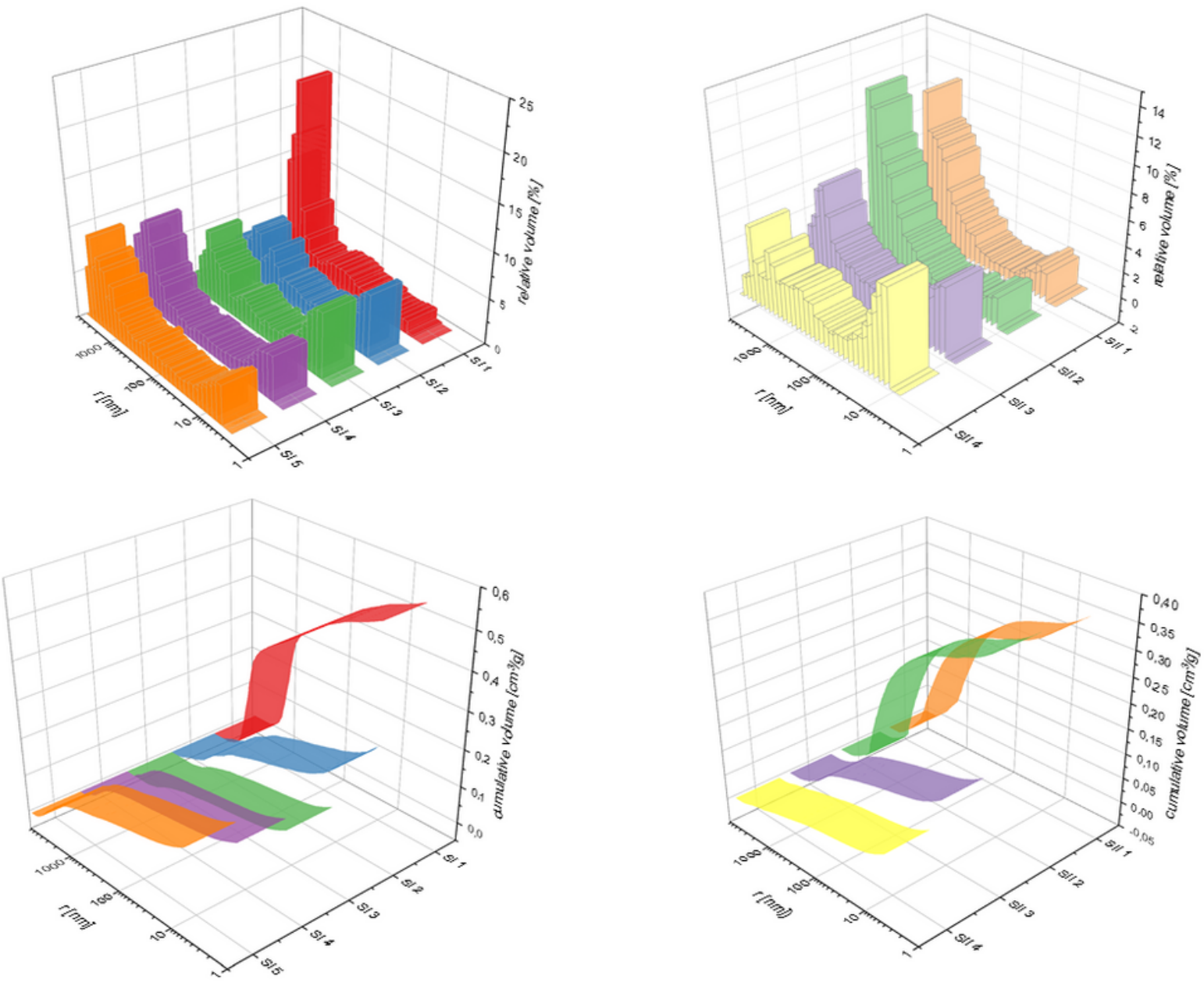

Figure 6

Histogram of pore volume depending on radius and pore filling curve as a function of growing pressure (series I on the left, series II on the right). 

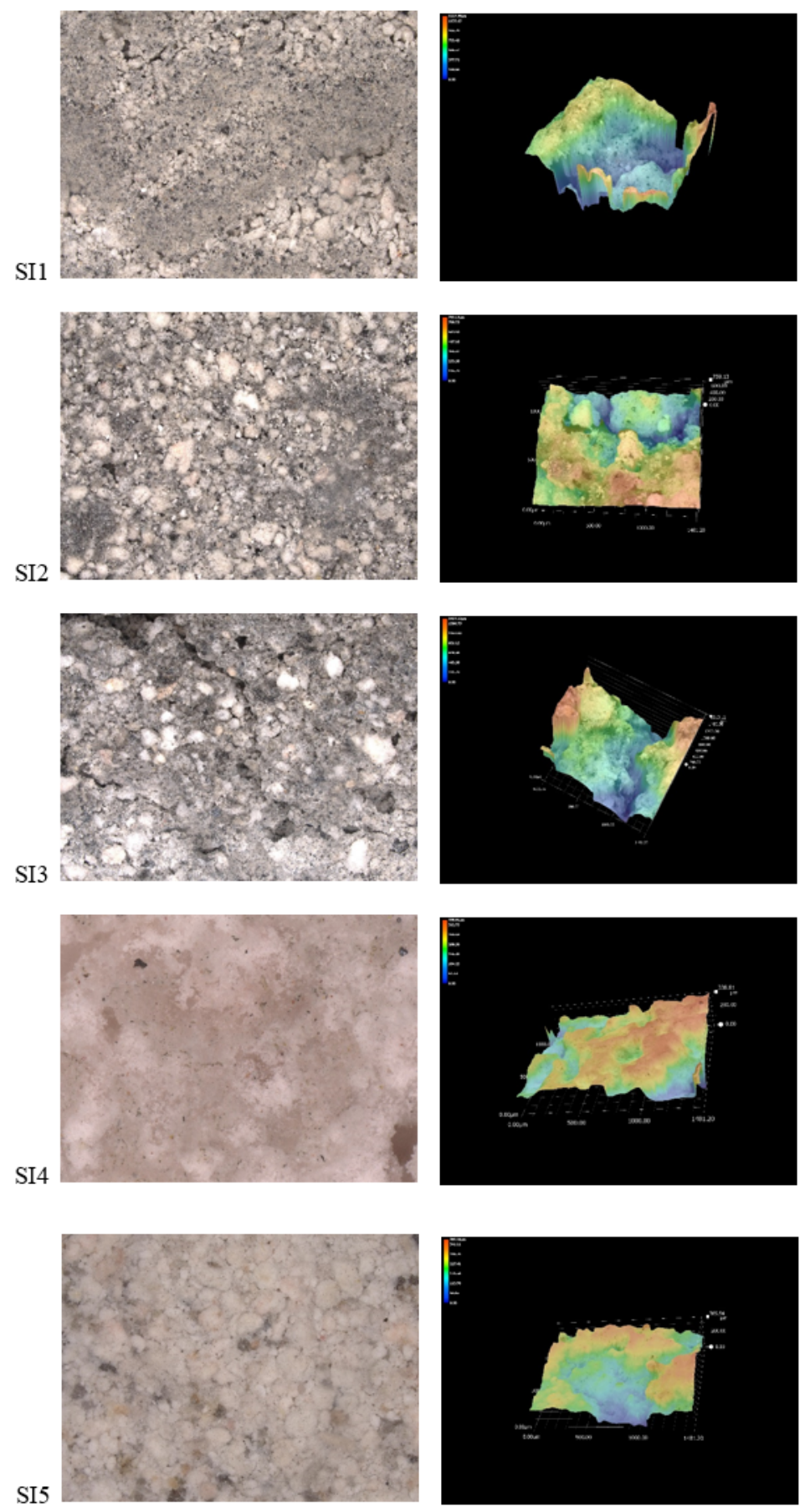

\section{Figure 7}

Microscopic pictures of the SI series. 

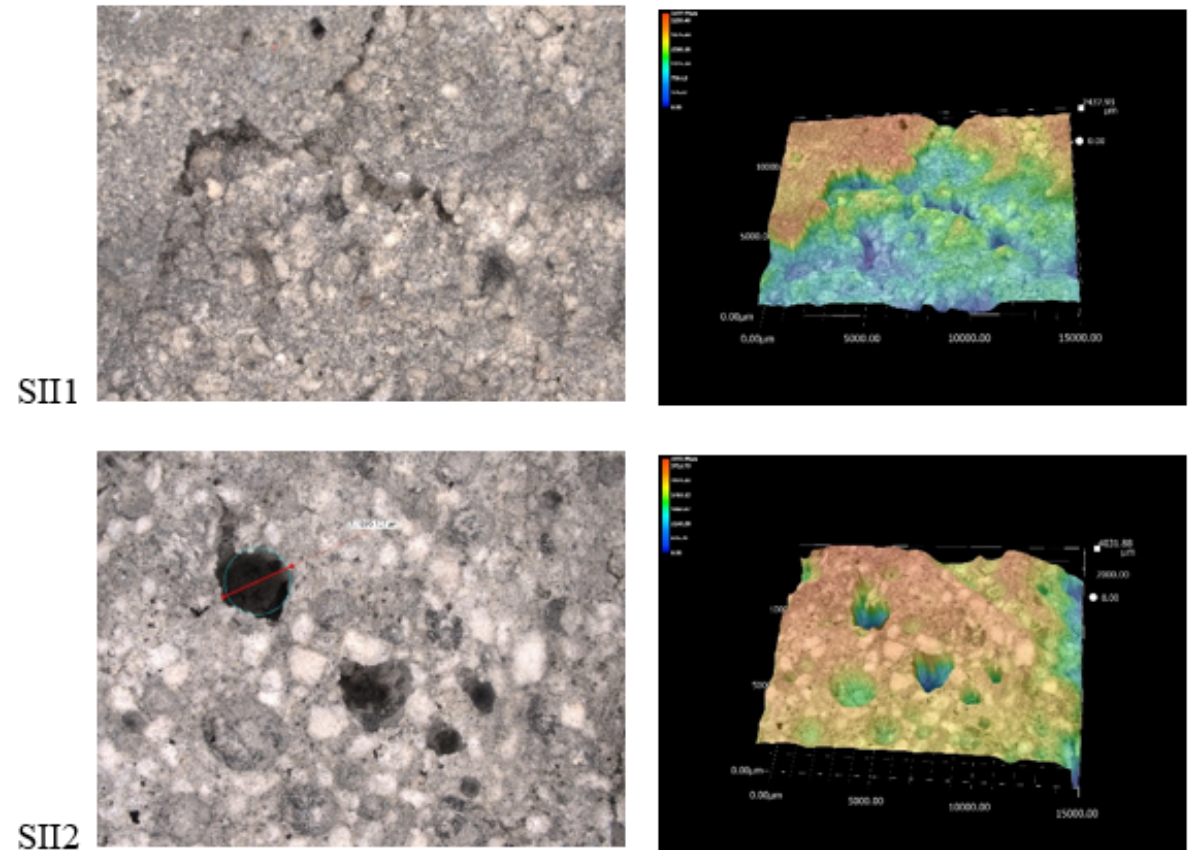

SII3
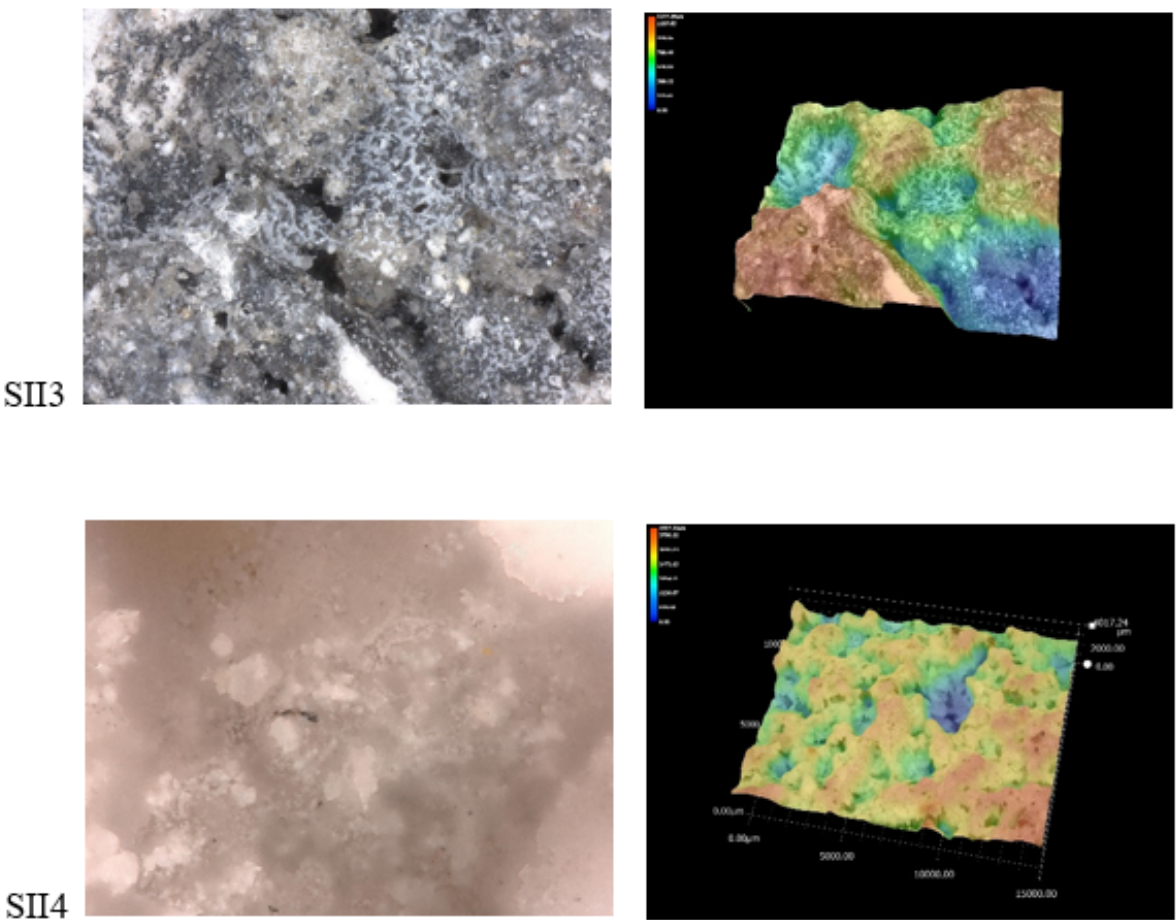

Figure 8

Microscopic pictures of the SII series. 


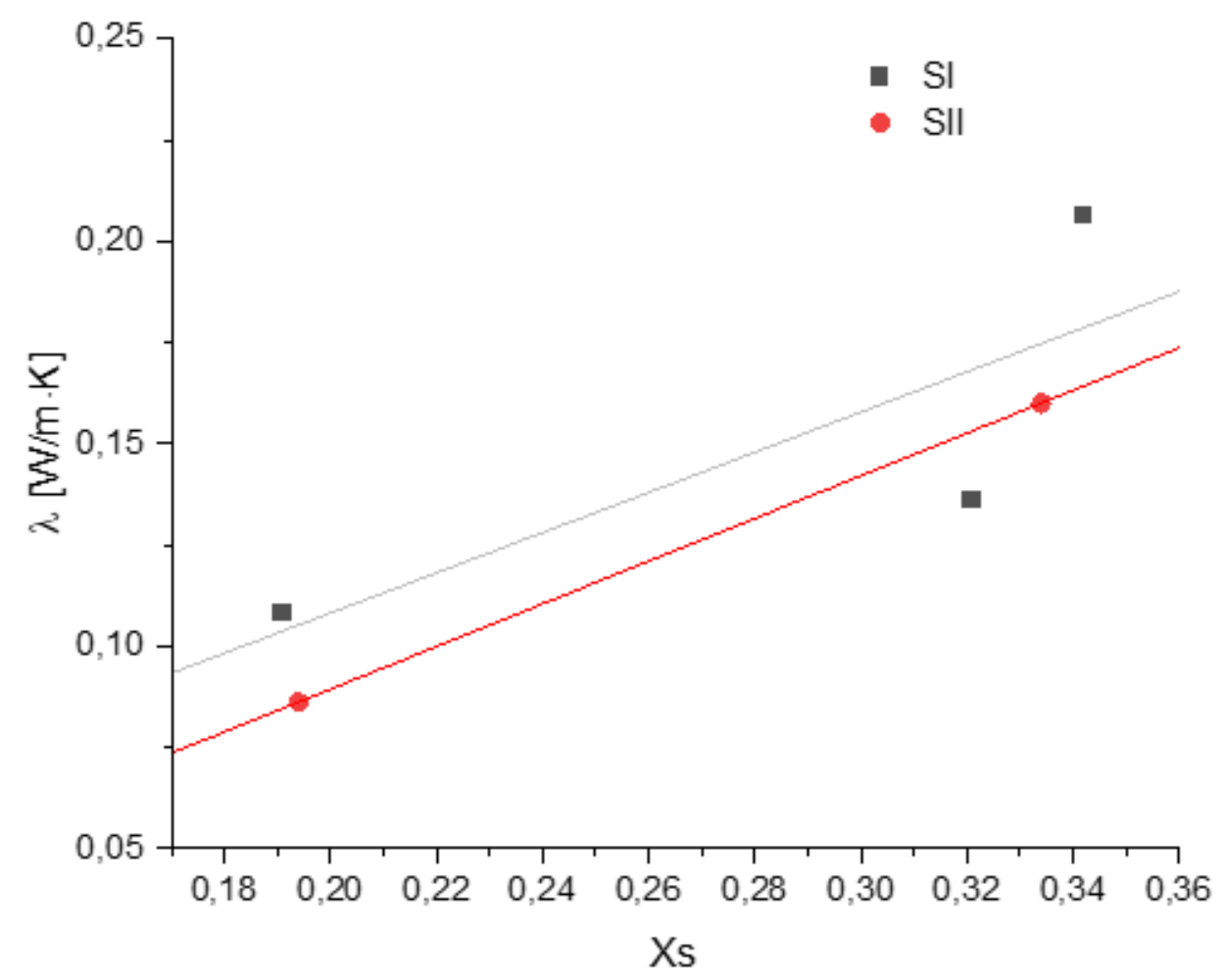

\section{Figure 9}

Changes in thermal conductivity of samples of SI and SII geopolymers with an increase in Xs - the fraction of solid components in the mixture (for $342 \mathrm{~K}$ )

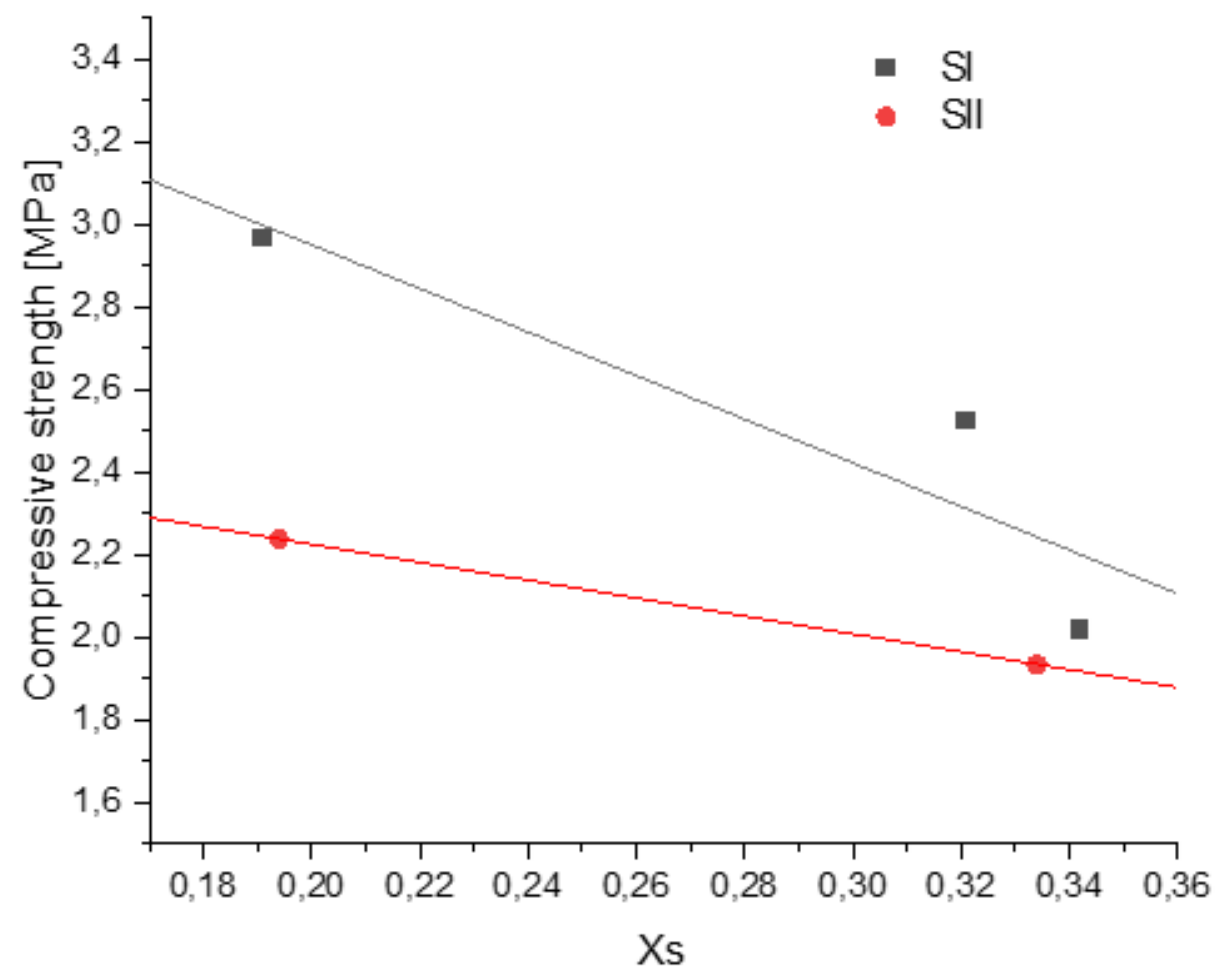


Figure 10

Changes in compressive strength of the SI and SII series geopolymers with an increase in Xs - the fraction of solid components in the mixture (for $342 \mathrm{~K}$ )

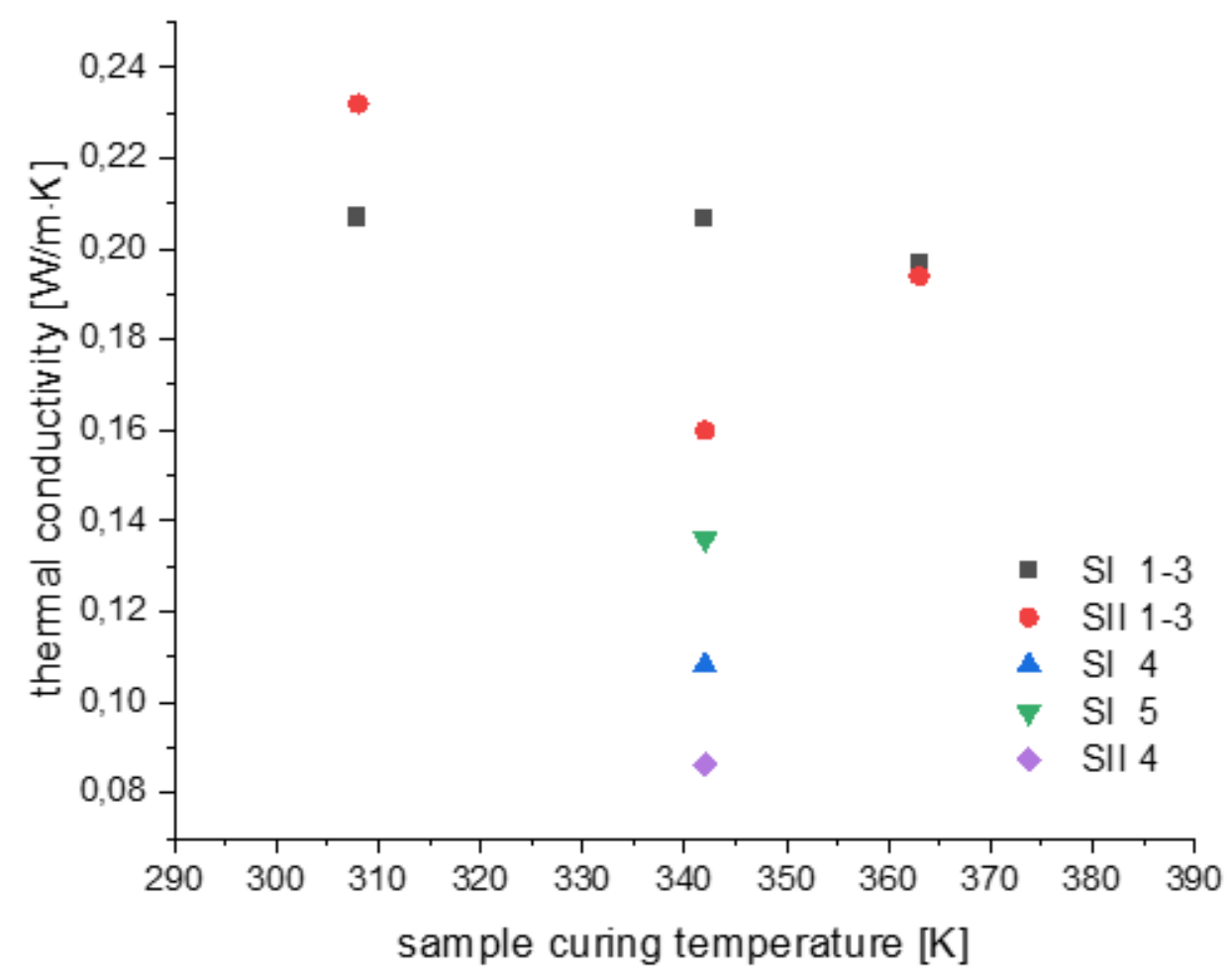

\section{Figure 11}

The thermal conductivity of geopolymers SI and SII series of various additives and curing temperatures mix 


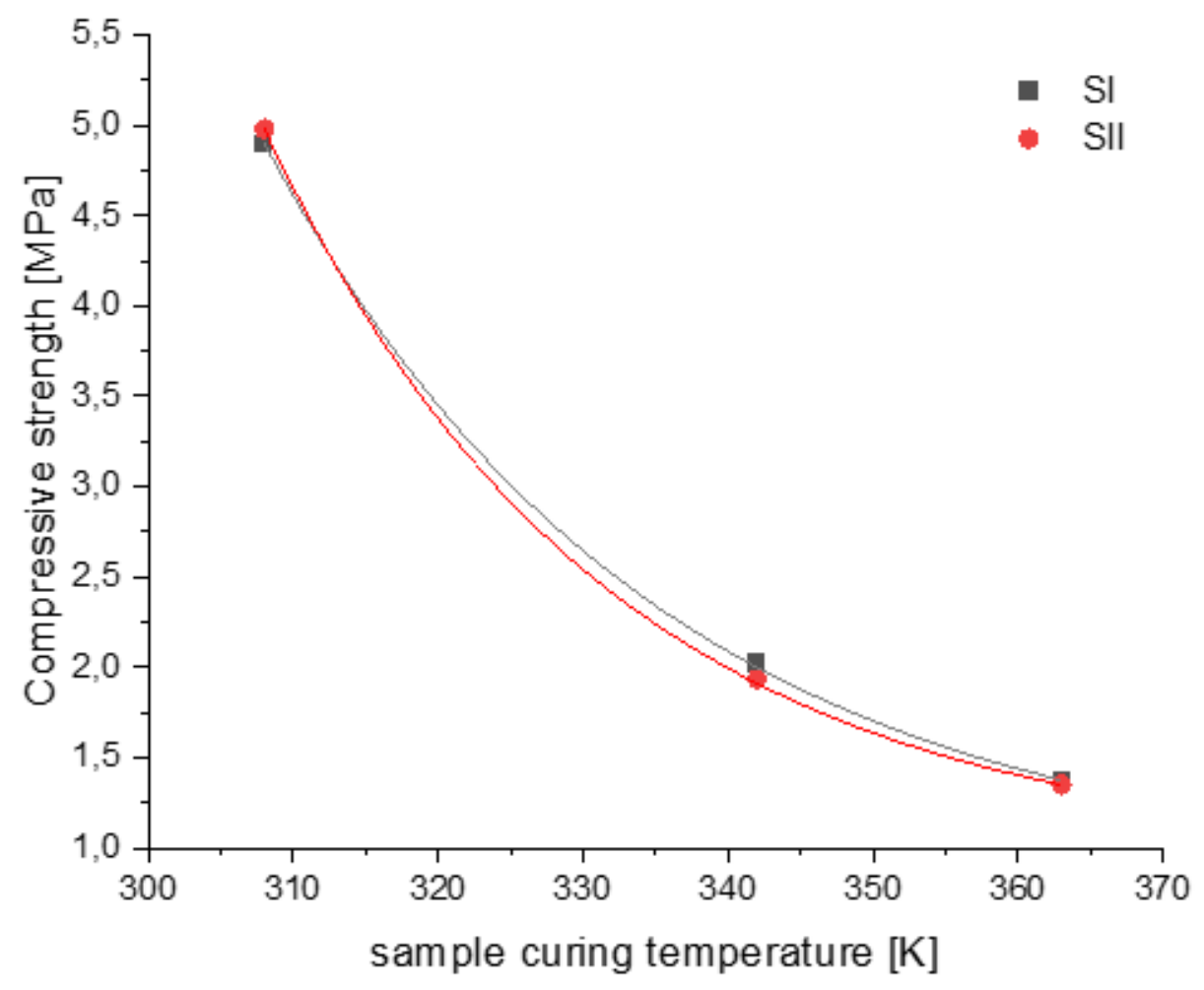

Figure 12

Compressive strength of SI- and SII-series geopolymers with increased curing temperature

\section{Supplementary Files}

This is a list of supplementary files associated with this preprint. Click to download.

- Graphicalabstract.pdf 